\title{
The Effects of Tolazoline on the Distribution of Cardiac Output in Normoxemic and Hypoxemic Lambs
}

\author{
G. A. GREGORY, G. LISTER, ${ }^{\prime}$ AND M. A. HEYMANN \\ Departments of Anesthesia and Pediatrics and the Cardiovascular Research Institute, University of California, \\ San Francisco, California 94143
}

\section{Summary}

We measured cardiac output and its distribution (microspheres), blood gases and $\mathrm{pH}$, heart rate, and pulmonary and aortic pressures in three groups of 1- to 3-day-old lambs.

Group I consisted of six animals who had these measurements made during both control (normoxemic) and hypoxemic $\left(\mathrm{PaO}_{2} 25\right.$ $\pm 3 \mathrm{~mm} \mathrm{Hg}$ ) periods. Hypoxemia increased the pulmonary artery pressure $70 \%(p<0.01)$. This elevation in pulmonary arterial pressure lasted as long as the animals were hypoxemic $(90 \mathrm{~min})$. Hypoxemia had no effect on cardiac output, mean systemic arterial pressure, heart rate, or the rate-pressure product of the left ventricle. Blood flow to the heart increased an average of $228 \%(p<0.05)$; flow to the brain increased $233 \%(p<0.05)$; flow to the skin decreased $35 \%(p<0.05)$ after 60 and 90 min of hypoxemia. Blood flow to the remaining organs was uneffected by hypoxemia.

Group II consisted of four animals who were given 1,5 , and $10 \mathrm{mg} / \mathrm{kg} / \mathrm{h}$ of tolazoline (Priscoline) intravenously while normoxemic. There was no effect on the pulmonary arterial pressures or blood gases and $\mathrm{pH}$. Tolazoline $(5$ and $10 \mathrm{mg} / \mathrm{kg} / \mathrm{h}$ ) reduced systemic arterial pressures an average of $22 \%(p<$ $0.05)$. Tolazoline $(1 \mathrm{mg} / \mathrm{kg} / \mathrm{h})$ reduced blood flow to the spleen $48 \%$ and that to the brain by $20 \%$ and increased flow to the body $32 \%(p<0.05)$. Five $\mathrm{mg} / \mathrm{kg} / \mathrm{h}$ of tolazoline decreased renal and brain blood flow 35 and $20 \%$, respectively $(p<0.05)$ while that to the body and liver increased 26 and $48 \%(p<0.05)$. Tolazoline $(10 \mathrm{mg} / \mathrm{kg} / \mathrm{h}$ ) returned splenic, body, and brain flow to control levels, and decreased renal blood flow further $(48 \%)(p<0.05)$. Tolazoline had no effect on the left ventricular rate-pressureproduct.

Group III was given 1,5 , and $10 \mathrm{mg} / \mathrm{kg} / \mathrm{h}$ of drug while the animals were hypoxemic $\left(\mathrm{PaO}_{2} 29 \pm 4 \mathrm{~mm} \mathrm{Hg}\right)$. The mean systemic arterial blood pressures decreased $20 \%$ with 5 and 10 $\mathrm{mg} / \mathrm{kg} / \mathrm{h}$ of tolazoline $(p<0.05)$, but tolazoline did not change mean pulmonary arterial pressure. Tolazoline had no effect on the left ventricular rate-pressure products. Cardiac output increased $47 \%$ with hypoxemia, but it was unaltered by the addition of tolazoline. Blood flow to the heart increased $300 \%$ and that to the brain $200 \%$ with hypoxemia and remained at these levels with infusing tolazoline. Flow to the remaining tissues was constant. Five $\mathrm{mg} / \mathrm{kg} / \mathrm{h}$ of tolazoline increased cardiac flow further (560\% of control). Ten $\mathrm{mg} / \mathrm{kg} / \mathrm{h}$ maintained the high cardiac flow

Received July 15, 1983; accepted February 7, 1984.

Address reprint requests to: G. A. Gregory, M.D., Professor of Anesthesia and Pediatrics, University of California, San Francisco, CA 94143.

This study was supported in part by Grant HO23681 from the National Institutes of Health.

${ }^{1}$ Associate Professor of Pediatrics and Anesthesia, Yale University School of Medicine, New Haven, CT 06510. Dr. Lister is supported in part by National Institutes of Health Grant HD15834. seen with $5 \mathrm{mg} / \mathrm{kg} / \mathrm{h}$ infusions of tolazoline, decreased that to the kidneys $33 \%$, and increased flow to the lower body $67 \%$. These data indicate that tolazoline does not decrease the pulmonary hypertension caused by hypoxemia and that tolazoline does little to alter the effect of hypoxemia on the distribution of blood flow.

At birth, there is an abrupt decline in the pulmonary arterial pressure, despite an increase in pulmonary blood flow (25). This decrease in pulmonary vascular resistance is attributed to alveolar expansion, an increase in the alveolar $\mathrm{PO}_{2}$ and a decrease in alveolar $\mathrm{PCO}_{2}$ (4), and possibly to the clearance of lung water (3). However, the pulmonary arterial pressure does not decrease to normal in some cases.

Regardless of the cause, persistence of pulmonary hypertension is usually attended by significant hypoxemia, and by intrapulmonary or extrapulmonary right-to-left shunting, or both. Because of this, numerous ventilatory maneuvers and vasodilating agents have been used in an attempt to decrease pulmonary arterial pressure and restore arterial oxygenation. Tolazoline is one such drug that has had extensive clinical use. However, the results have been quite variable. In some cases, infusion of tolazoline is attended by a marked fall in pulmonary arterial pressure and increase in arterial $\mathrm{PO}_{2}$. In others there has been no improvement or a worsening of the patient's condition $(5,11$, 15). Of additional importance is the fact that the use of tolazoline has been associated with numerous untoward effects, including gastrointestinal bleeding, renal failure, intracranial hemorrhage, and systemic hypotension $(12,24,26,27)$.

The causes of these untoward effects are unknown, but might be related to the effects of tolazoline on cardiac output and its distribution; this could be of particular concern during abnormal physiologic states such as hypoxemia. To our knowledge, the affect of tolazoline on cardiac ouput and its distribution has not been studied previously. Since these studies could not be done in humans, we examined the effects of tolazoline on intravascular pressures and on cardiac ouput and its distribution in normoxemic and hypoxemic 1- to 3-day-old lambs.

\section{MATERIALS AND METHODS}

Subjects. We studied 15 healthy, awake, intact, and unsedated lambs who were less than 4 days old $(3.9 \pm 0.4 \mathrm{~kg})$. Four animals were used to evaluate the effects of hypoxemia and time on the model (Group I); four were used to evaluate the effects of tolazoline in normoxemic animals (Group II); and seven were used to evaluate the effects of tolazoline in hypoxemic animals (Group III).

Preparation. The lambs were blindfolded and placed in the lateral recumbent position on a table where they lay quietly. 
Following injections of local anesthetic, catheters were inserted into a femoral artery and vein through a groin incision and into the left ventricle and ascending aorta through a carotid artery. A flow-directed catheter was inserted into the pulmonary artery via the right jugular vein. The arterial and ventricular catheters were connected to strain gauges (Statham P23DB) whose outputs were recorded on a Beckman Dynagraph.

Protocol. When the vital signs were stable for 15 to $30 \mathrm{~min}$, we measured arterial blood gases and $\mathrm{pH}_{\mathrm{a}}$ (Radiometer, Copenhagen, Denmark) and the intravascular pressures, and determined cardiac ouput and its distribution with $15-\mu \mathrm{m}$ radioactive microspheres (23). Cardiac ouput was determined by summing the blood flow to all of the organs. The spheres were injected into the left ventricle and their concentration in blood was measured by simultaneously withdrawing blood from the ascending and descending aorta for 1 or $1.5 \mathrm{~min}$. Control measurements were made while the animals were breathing room air. Blood losses were replaced with maternal blood.

Hypoxemia control group (Group I). After completing the control measurements, we measured the intravascular pressures, cardiac output and its distribution, and blood gases and $\mathrm{pH}$ in four animals after 30,60 , and 90 min of hypoxemia $\left(\mathrm{PaO}_{2} 25 \pm\right.$ 3 to $32 \pm 3 \mathrm{~mm} \mathrm{Hg}$ ). In these and subsequent animals, hypoxemia was produced by placing a large plastic bag over the lamb's head and snout and replacing a fraction of the inspired air with nitrogen. After completing the measurements during hypoxemia, the animals were again studied when normoxemic. These four lambs received no tolazoline and were used to assess the effects of hypoxemia per se and the stability of the preparation over time.

Tolazoline control group (Group II). After making the control measurements, we measured the intravascular pressures, cardiac ouput and its distribution, and blood gases and $\mathrm{pH}$, during normoxemia plus tolazoline. We infused $1 \mathrm{mg} / \mathrm{kg}$ of tolazoline over $15 \mathrm{~s}$ and followed it with an infusion of 1,5 , and $10 \mathrm{mg} /$ $\mathrm{kg} / \mathrm{h}$ of tolazoline. Fifteen min after beginning the infusion of each dose of tolazoline, we repeated all of the measurements listed above. These lambs were used to assess the effects of tolazoline on cardiac ouput and its distribution in the normoxemic state.

Tolazoline plus hypoxemia (Group III). Following control measurements during normoxemia, we made the animals hypoxemic $\left(\mathrm{PaO}_{2} 23 \pm 4 \mathrm{~mm} \mathrm{Hg}, \mathrm{SD}\right)$. Carbon dioxide was not added to the inspired gas to maintain a constant $\mathrm{PaCO}_{2}$. After 15 min of hypoxemia, the blood gases, intravascular pressures, and the cardiac output and its distribution were again measured. Next, we administered $1 \mathrm{mg} / \mathrm{kg}$ of tolazoline over $15 \mathrm{~s}$ and followed it with a continuous infusion of 1,5 , and then $10 \mathrm{mg} /$ $\mathrm{kg} / \mathrm{h}$ of the drug. Fifteen min after beginning the continuous infusion of each dose of tolazoline, and when the heart rate and mean arterial pressure were constant for at least $5 \mathrm{~min}$, we remeasured the intravascular pressures, blood gases, $\mathrm{pH}$, and the cardiac output and its distribution.

All animals were killed with an overdose of barbiturate and potassium chloride. Their organs were removed and ashed as previously described (23). Data were compared by repeated measures and the Bonferroni test for differences between groups (10).

\section{RESULTS}

Blood gases, $\mathrm{pH}_{a}$, and intravascular pressures. Blood gases, $\mathrm{pH}_{\mathrm{a}}$, and intravascular pressures of the control and the test animals are given in Tables 1-3. In Group $\mathrm{I}$, the $\mathrm{PaO}_{2}$ and $\mathrm{PaCO}_{2}$ decreased and the $\mathrm{pH}$ rose with the onset of hypoxemia $(p<$ 0.01 ) and were constant for the remainder of the hypoxemic period $(90 \mathrm{~min})$. The mean systemic arterial pressure of Group I was unchanged by hypoxemia. Mean pulmonary artery pressures, on the other hand, increased significantly with the onset of hypoxemia and remained elevated as long as the animals were hypoxemic. When the animals again breathed room air for 15 min, their blood gases and $\mathrm{pH}$ and their mean systemic and pulmonary arterial pressures all returned to control levels, indicating that the preparation was stable during the $90-\mathrm{min}$ period of hypoxemia. This was also the duration of our studies in the lambs given tolazoline.

In Group II (normoxemia plus tolazoline), there was no significant change in blood gases, $\mathrm{pH}$, pulmonary artery pressures, heart rate, or left ventricular rate-pressure-product with the infusion of tolazoline (Table 2). The mean systemic arterial pressures descreased $(p<0.05)$ with the infusion of 5 and 10 $\mathrm{mg} / \mathrm{kg} / \mathrm{h}$ of tolazoline.

In Group III, the heart rates, mean intravascular pressures, blood gases, and $\mathrm{pH}$ values were within normal limits for animals of this age during the normoxemic period $(19,21)$ (Table 3 ). The mean pulmonary artery pressure increased from $27 \pm 4 \mathrm{~mm} \mathrm{Hg}$

Table 1. The effects of hypoxemia on arterial blood gases, $p H$, intravascular pressures and rate-pressure product

\begin{tabular}{lccccccc}
\hline & $\mathrm{PaO}_{2}(\mathrm{~mm} \mathrm{Hg})$ & $\mathrm{PaCO}_{2}(\mathrm{~mm} \mathrm{Hg})$ & $\mathrm{pH}$ & $\mathrm{MAP}(\mathrm{mm} \mathrm{Hg})$ & $\mathrm{MPAP}(\mathrm{mm} \mathrm{Hg})$ & $\mathrm{HR}(\mathrm{bpm})$ & $\mathrm{RPP}(\mathrm{mm} \mathrm{Hg} \cdot \mathrm{bpm})$ \\
\hline $\begin{array}{l}\text { Normoxemia } \\
\text { Hypoxemia }\end{array}$ & $80 \pm 8$ & $39 \pm 3$ & $7.42 \pm .01$ & $108 \pm 12$ & $30 \pm 7$ & $184 \pm 15$ & $19,872 \pm 298$ \\
$30 \mathrm{~min}$ & $25 \pm 3 \dagger$ & $33 \pm 4 \dagger$ & $7.48 \pm .06 \dagger$ & $90 \pm 15$ & $51 \pm 5 \dagger$ & $175 \pm 18$ & $15,750 \pm 263$ \\
$60 \mathrm{~min}$ & $29 \pm 2 \dagger$ & $30 \pm 3 \dagger$ & $7.44 \pm .01$ & $95 \pm 14$ & $54 \pm 7 \dagger$ & $195 \pm 17$ & $18,525 \pm 277$ \\
$90 \mathrm{~min}$ & $32 \pm 3 \dagger$ & $34 \pm 3 \dagger$ & $7.39 \pm .01$ & $125 \pm 12$ & $56 \pm 7 \dagger$ & $191 \pm 15$ & $23,875 \pm 307$ \\
Normoxemia & $84 \pm 7$ & $39 \pm 5$ & $7.40 \pm .02$ & $112 \pm 13$ & $28 \pm 6$ & $180 \pm 20$ & $21,082 \pm 358$ \\
\hline
\end{tabular}

* MAP, mean arterial pressure; MPAP, mean pulmonary artery pressure; HR, heart rate; RPP, rate-pressure product; bpm, beats/min. Values are means $\pm \mathrm{SD}$.

† Significantly different from normoxemia at the $p<0.05$ level.

Table 2. The effects of tolazoline on arterial blood gases, $\mathrm{pH}$, intravascular pressures, and rate-pressure product of normoxemic lambs

\begin{tabular}{|c|c|c|c|c|c|c|c|}
\hline & $\mathrm{PaO}_{2}(\mathrm{~mm} \mathrm{Hg})$ & $\mathrm{PaCO}_{2}(\mathrm{~mm} \mathrm{Hg})$ & $\mathrm{pH}$ & $\mathrm{MAP}(\mathrm{mm} \mathrm{Hg})$ & MPAP $(\mathrm{mm} \mathrm{Hg})$ & HR (bpm) & $\mathrm{RPP}(\mathrm{mm} \mathrm{Hg} \cdot \mathrm{s})$ \\
\hline $\begin{array}{l}\text { Normoxemia (no drug) } \\
\text { Normoxemia + tolazoline } \\
\quad(\mathrm{mg} / \mathrm{kg} / \mathrm{h})\end{array}$ & $71 \pm 7$ & $40 \pm 3$ & $7.41 \pm 0.04$ & $87 \pm 14$ & $27 \pm 4$ & $222 \pm 33$ & $19,158 \pm 2,833$ \\
\hline $\begin{array}{r}1 \\
5 \\
10\end{array}$ & $\begin{array}{l}65 \pm 8 \\
62 \pm 1 \\
66 \pm 7\end{array}$ & $\begin{array}{l}40 \pm 3 \\
42 \pm 2 \\
45 \pm 6\end{array}$ & $\begin{array}{l}7.40 \pm 0.02 \\
7.38 \pm 0.02 \\
7.35 \pm 0.06\end{array}$ & $\begin{array}{l}84 \pm 9 \\
76 \pm 15 \dagger \\
61 \pm 19 \dagger\end{array}$ & $\begin{array}{l}27 \pm 1 \\
27 \pm 1 \\
27 \pm 3\end{array}$ & $\begin{array}{l}267 \pm 30 \\
282 \pm 37 \\
269 \pm 23\end{array}$ & $\begin{array}{l}22,515 \pm 3,333 \\
21,695 \pm 6,774 \\
16,610 \pm 5,867\end{array}$ \\
\hline
\end{tabular}

- MAP, mean arterial pressure; MPAP, mean pulmonary arterial pressure; HR, heart rate; RPP, rate-pressure product; bpm, beats/min.

$\dagger$ Significantly different from no drug $(p<0.05)$. 
(control) to $51 \pm 6 \mathrm{~mm} \mathrm{Hg}$ when the animals were hypoxemic $(p<0.01)$. When tolazoline was infused, it did not reduce the pulmonary arterial pressure, nor did it change the heart rate, blood gases, or $\mathrm{pH}$ from those during hypoxemia alone (Table $3)$. The left ventricular rate-pressure products were unchanged by either hypoxemia or hypoxemia plus tolazoline.

In all three groups of animals, blood drawn from the ascending aorta and femoral artery had the same $\mathrm{PaO}_{2}$. Therefore, we assumed that there was no right-to-left shunting of blood through the ductus arteriosus.

Tissue blood flow ( $\mathrm{ml} / 100 \mathrm{~g} / \mathrm{min}$ ). Table 4 shows the effects of hypoxemia and time on the blood flow $(\mathrm{ml} / 100 \mathrm{~g} / \mathrm{min})$ in Group I. Brain flow was increased significantly above control throughout the hypoxemic periods. It returned towards control levels when the animals were made normoxemic at the end of the study. Skin flow was decreased after 90 min of hypoxemia and during the return to normoxemia. Blood flow to the heart increased during hypoxemia but, because of large standard deviations, the changes were not statistically significant. Cardiac ouput increased significantly. There was no significant change in flow to the other organs.

Table 5 shows the effects of tolazoline on organ blood flow $(\mathrm{ml} / 100 \mathrm{~g} / \mathrm{min}$ ) in Group II (tolazoline and normoxemia). One $\mathrm{mg} / \mathrm{kg} / \mathrm{h}$ tolazoline increased blood flow to the carcass. The same dose decreased blood flow to the spleen and brain, despite an increase in cardiac ouput. Five $\mathrm{mg} / \mathrm{kg} / \mathrm{h}$ decreased gut, kidney, and brain blood flow $(p<0.05)$. Flow to the liver and body were increased $(p<0.05)$. Ten $\mathrm{mg} / \mathrm{kg} / \mathrm{h}$ of tolazoline increased splenic flow further and increased pulmonary flow. Renal flow was similar to that at $5 \mathrm{mg} / \mathrm{kg} / \mathrm{h}$ of tolazoline. Gut, body, and brain flows returned to control levels.
Table 6 shows the effects of tolazoline on the blood flow $(\mathrm{ml} /$ $100 \mathrm{~g} / \mathrm{min}$ ) of Group III (hypoxemia plus tolazoline). The flow to the heart tripled and that to the brain doubled with the onset of hypoxemia. One $\mathrm{mg} / \mathrm{kg} / \mathrm{h}$ of tolazoline maintained the flow to heart and brain at levels attained with hypoxemia alone but did not increase it further. Five $\mathrm{mg} / \mathrm{kg} / \mathrm{h}$ of tolazoline increased myocardial flow further while maintaining cerebral flow at levels achieved with hypoxemia alone. Lung flow increased. Ten $\mathrm{mg} /$ $\mathrm{kg} / \mathrm{h}$ of tolazoline maintained blood flow to the brain and heart at those levels seen with infusion of $5 \mathrm{mg} / \mathrm{kg} / \mathrm{h}$. Renal blood flow decreased below control levels, and flow to the lower body increased.

\section{DISCUSSION}

Pulmonary hypertension usually decreases pulmonary blood flow and causes right-to-left shunting of blood through the ductus arteriosus and/or the foramen ovale in neonates. This leads to hypoxemia. Tolazoline is the drug most commonly used to try to reduce the pulmonary vascular resistance of such patients and increase their pulmonary blood flow. Unfortunately, tolazoline is effective in doing so in only about half of the patients, probably because it has multiple pharmacologic effects $(1,12-14,29,31)$. As a consequence, the effect of this drug on the pulmonary vascular resistance and pressure depends on which of its several pharmacologic effects predominates. At present we are unable to tell a priori which one will do so.

Our studies indicate that tolazoline has no effect on the pulmonary artery pressures of either normoxemic or hypoxemic animals. This finding has previously been reported in humans and animals $(6,24,28)$. Although pulmonary vascular resistance

Table 3. The effects of tolazoline on arterial blood gases, $p H$, intravascular pressures, and rate-pressure product of hypoxemic lambs

\begin{tabular}{|c|c|c|c|c|c|c|c|}
\hline & $\mathrm{PaO}_{2}(\mathrm{~mm} \mathrm{Hg})$ & $\mathrm{PaCO}_{2}(\mathrm{~mm} \mathrm{Hg})$ & $\mathrm{pH}$ & MAP (mm Hg) & $\operatorname{MPAP}(\mathrm{mm} \mathrm{Hg})$ & HR (bpm) & $\mathrm{RPP}(\mathrm{mm} \mathrm{Hg} \cdot \mathrm{bpm})$ \\
\hline Normoxemia & $76 \pm 6$ & $38 \pm 3$ & $7.42 \pm 0.03$ & $81 \pm 9$ & $27 \pm 4$ & $190 \pm 20$ & $15,390 \pm 2,165$ \\
\hline Hypoxemia & $23 \pm 3 \dagger$ & $29 \pm 4 \dagger$ & $7.45 \pm 0.06$ & $72 \pm 8$ & $51 \pm 6 \dagger$ & $245 \pm 24 \dagger$ & $17,640 \pm 1,983$ \\
\hline \multicolumn{8}{|c|}{$\begin{array}{l}\text { Hypoxemia + tolazoline } \\
\qquad(\mathrm{mg} / \mathrm{kg} / \mathrm{h})\end{array}$} \\
\hline 1 & $29 \pm 4 \dagger$ & $28 \pm 4 \dagger$ & $7.43 \pm 0.06$ & $73 \pm 8$ & $54 \pm 2 \dagger$ & $263 \pm 24 \uparrow$ & $19,199 \pm 2,305$ \\
\hline 5 & $28 \pm 2 \dagger$ & $28 \pm 3 \dagger$ & $7.38 \pm 0.10 \dagger$ & $63 \pm 5 \dagger$ & $56 \pm 5 \dagger$ & $258 \pm 24 \dagger$ & $16,254 \pm 2,321$ \\
\hline 10 & $26 \pm 2 \dagger$ & $28 \pm 4 \dagger$ & $7.38 \pm 0.08 \dagger$ & $66 \pm 8 \dagger$ & $52 \pm 8 \dagger$ & $254 \pm 29 \dagger$ & $16,764 \pm 2,016$ \\
\hline
\end{tabular}

* MAP, mean arterial pressure; MPAP, mean pulmonary arterial pressure; HR, heart rate; RPP, rate-pressure product; bpm, beats/min.

$\dagger$ Significantly different from normoxemic control $(p<0.05$ level).

Table 4. The effects of hypoxemia on cardiac output and organ blood flow ( $\mathrm{ml} / \mathrm{min} / 100 \mathrm{~g}$ of tissue)

\begin{tabular}{|c|c|c|c|c|c|c|c|c|c|c|}
\hline & $\begin{array}{l}\text { Cardiac output } \\
(\mathrm{ml} / \mathrm{min})\end{array}$ & Heart & Brain & Kidney & Gut & Liver & Spleen & Skin & Carcass & Lung \\
\hline $\begin{array}{l}\text { Normoxemia } \\
\text { Hypoxemia }\end{array}$ & $1480 \pm 423$ & $414 \pm 605$ & $59 \pm 39$ & $278 \pm 28$ & $114 \pm 45$ & $23 \pm 9$ & $287 \pm 451$ & $20 \pm 18$ & $20 \pm 17$ & $137 \pm 138$ \\
\hline $30 \mathrm{~min}$ & $1863 \pm 368^{*}$ & $1064 \pm 461^{\circ}$ & $140 \pm 10^{*}$ & $274 \pm 41^{*}$ & $118 \pm 10$ & $47 \pm 19$ & $346 \pm 224$ & $9 \pm 14$ & $24 \pm 13$ & $116 \pm 105$ \\
\hline $60 \mathrm{~min}$ & $1505 \pm 536^{\circ}$ & $882 \pm 212^{\circ}$ & $128 \pm 31^{*}$ & $214 \pm 11^{\circ}$ & $107 \pm 3$ & $27 \pm 16$ & $193 \pm 6$ & $15 \pm 7$ & $25 \pm 10$ & $97 \pm 82$ \\
\hline $90 \mathrm{~min}$ & $1725 \pm 385^{\circ}$ & $945 \pm 299^{*}$ & $136 \pm 61^{*}$ & $153 \pm 72^{*}$ & $75 \pm 33$ & $28 \pm 31$ & $132 \pm 204^{*}$ & $13 \pm 2^{*}$ & $32 \pm 6$ & $20 \pm 1$ \\
\hline Return to control & $1329 \pm 13$ & $382 \pm 37$ & $95 \pm 10$ & $253 \pm 126$ & $118 \pm 28$ & $27 \pm 12$ & $205 \pm 194$ & $13 \pm 2^{*}$ & $19 \pm 1$ & $36 \pm 5^{\circ}$ \\
\hline
\end{tabular}

* Significantly different from normoxemia $(p<0.05)$.

Table 5. Effects of tolazoline on cardiac and organ blood flow ( $\mathrm{ml} / \mathrm{min} / 100 \mathrm{~g}$ of tissue) of normoxemic lambs

\begin{tabular}{|c|c|c|c|c|c|c|c|c|c|c|}
\hline & $\begin{array}{l}\text { Cardiac output } \\
(\mathrm{ml} / \mathrm{min})\end{array}$ & Heart & Brain & Kidney & Gut & Liver & Spleen & Skin & Carcass & Lung \\
\hline $\begin{array}{l}\text { Normoxemia (no drug) } \\
\text { Normoxemia + tolazoline } \\
\quad(\mathrm{mg} / \mathrm{kg} / \mathrm{h})\end{array}$ & $979 \pm 137$ & $55 \pm 16$ & $72 \pm 6$ & $226 \pm 77$ & $84 \pm 4$ & $27 \pm 40$ & $443 \pm 185$ & $13 \pm 7$ & $19 \pm 3$ & $83 \pm 81$ \\
\hline $\begin{array}{r}1 \\
5 \\
10\end{array}$ & $\begin{array}{l}1209 \pm 142^{*} \\
1119 \pm 127 \\
1272 \pm 22\end{array}$ & $\begin{array}{l}69 \pm 23 \\
78 \pm 33 \\
76 \pm 25\end{array}$ & $\begin{array}{l}58 \pm 10^{*} \\
58 \pm 3^{*} \\
77 \pm 5\end{array}$ & $\begin{array}{l}234 \pm 23 \\
146 \pm 75^{*} \\
139 \pm 27^{*}\end{array}$ & $\begin{array}{l}70 \pm 17 \\
53 \pm 18^{*} \\
91 \pm 2\end{array}$ & $\begin{array}{l}59 \pm 34 \\
40 \pm 25^{*} \\
13 \pm 7\end{array}$ & $\begin{array}{l}230 \pm 120^{*} \\
381 \pm 191 \\
625 \pm 5^{*}\end{array}$ & $\begin{aligned} 12 & \pm 5 \\
9 & \pm 0.2 \\
15 & \pm 5\end{aligned}$ & $\begin{array}{l}25 \pm 2^{*} \\
24 \pm 2^{*} \\
17 \pm .7\end{array}$ & $\begin{array}{r}88 \pm 51 \\
119 \pm 46 \\
158 \pm 26\end{array}$ \\
\hline
\end{tabular}

- Significantly different from normoxemia $(p<0.05)$. 
Table 6. The effects of tolazoline on cardiac output and organ blood flow ( $\mathrm{ml} / \mathrm{min} / 100 \mathrm{~g}$ of tissue) of hypoxemic lambs

\begin{tabular}{|c|c|c|c|c|c|c|c|c|c|c|}
\hline & $\begin{array}{c}\text { Cardiac output } \\
(\mathrm{ml} / \mathrm{min})\end{array}$ & Heart & Brain & Kidney & Gut & Liver & Spleen & Skin & Carcass & Lung \\
\hline Normoxemia & $956 \pm 75$ & $149 \pm 53$ & $65 \pm 20$ & $251 \pm 54$ & $125 \pm 34$ & $49 \pm 87$ & $263 \pm 163$ & $11 \pm 7$ & $16 \pm 4$ & $164 \pm 115$ \\
\hline Hypoxemia & $1404 \pm 132^{*}$ & $446 \pm 78$ & $131 \pm 41^{\circ}$ & $235 \pm 81$ & $123 \pm 49$ & $52 \pm 60$ & $224 \pm 210$ & $11 \pm 6$ & $20 \pm 8$ & $153 \pm 141$ \\
\hline \multicolumn{11}{|c|}{$\begin{array}{l}\text { Hypoxemia + tolazoline } \\
(\mathrm{mg} / \mathrm{kg} / \mathrm{h})\end{array}$} \\
\hline 1 & $1313 \pm 62^{*}$ & $521 \pm 421^{*}$ & $132 \pm 37^{*}$ & $196 \pm 59$ & $100 \pm 41$ & $36 \pm 20$ & $171 \pm 108$ & $8 \pm 4$ & $23 \pm 8$ & $277 \pm 247$ \\
\hline 5 & $1500 \pm 240$ & $833 \pm 486^{\circ} \dagger$ & $159 \pm 50^{*}$ & $209 \pm 119$ & $123 \pm 61$ & $44 \pm 13$ & $210 \pm 185$ & $11 \pm 10$ & $31 \pm 22$ & $372 \pm 196^{*} \dagger$ \\
\hline 10 & $1478 \pm 190$ & $710 \pm 350^{\circ}$ & $113 \pm 14^{*}$ & $169 \pm 55^{*} \dagger$ & $136 \pm 61$ & $48 \pm 13$ & $224 \pm 355$ & $10 \pm 10$ & $30 \pm 15 \dagger$ & $294 \pm 120$ \\
\hline
\end{tabular}

* Significantly different from control $(p<0.05)$.

$\dagger$ Significantly different from hypoxemia $(p<0.05)$.

was not determined, it is likely that it was little affected by tolazoline in the hypoxemic animals because pulmonary blood flow and pressure were similar to those present during hypoxemia alone. Tripp et al. (28) found that both pulmonary vascular resistance and pulmonary/systemic vascular resistance ratios of hypoxemic lambs increased during tolazoline infusion. They found an increase in the ratio of pulmonary to systemic artery pressures. We also found a rise in pulmonary/systemic arterial pressure ratio. Since the levels of cardiac ouput were similar during hypoxemia and hypoxemia plus tolazoline, it is likely that our animals had similar changes in pulmonary and peripheral vascular resistance to those reported by Tripp et al.

The hypoxemic lamb may not be the ideal model of the persistent pulmonary hypertension seen in infants because the two differ in their response to oxygen. Infants usually have little or no improvement in oxygenation and no reduction in pulmonary artery pressure with increasing the inspired oxygen concentration, even to $100 \%(6)$. Both pressure and oxygenation returned to normal when the inspired oxygen concentration of our lambs was increased to that of room air. We conclude from this that the pulmonary hypertension seen in infants with primary pulmonary hypertension is due to factors besides hypoxemic pulmonary arterial constriction alone.

Blood gases often worsen when tolazoline is administered to infants who have pulmonary hypertension $(6,22)$. There are several possible reasons for this. 1) There may be interference with hypoxemic pulmonary vasoconstriction in areas where the ventilation/perfusion ratio is low or zero, thereby increasing venous admixture. 2) Tolazoline may decrease systemic vascular resistance more than pulmonary vascular resistance and promote right-to-left shunting of blood through the foramen ovale. 3) Tolazoline may reduce systemic vascular resistance more than pulmonary vascular resistance, which, in the presence of a large patent ductus arteriosus, would allow right-to-left shunting through the ductus arteriosus. 4) Tolazoline might decrease cardiac output, which would decrease mixed venous oxygen tension. This would decrease $\mathrm{PaO}_{2}$. In our study, the pulmonary arterial pressure was always less than the systemic pressure and the $\mathrm{PaO}_{2}$ values above and below the ductus arteriosus were equal; therefore, shunting did not occur through the ductus arteriosus. Cardiac ouput was always at or above control levels when tolazoline was administered. Since tolazoline did not affect aortic oxygen tension during hypoxemia, we conclude that tolazoline caused neither a redistribution of pulmonary blood flow nor a change in transatrial shunting.

We studied three groups of animals to define 1) the effects of hypoxemia without tolazoline, 2) the effects of tolazoline in normoxemic animals, and 3) the effects of tolazoline in hypoxemic animals. The first group of animals was used to define the effects of hypoxemia and of time. The variables measured were stable throughout the 90 -min period of hypoxemia and returned to control levels with return to normoxemia. From this we conclude that the preparation was stable. Thus, changes in these variables with infusing tolazoline into hypoxemic animals would be due to tolazoline and not to hypoxemia or time per se.

The second group was used to determine the effects of tola- zoline in normoxemic animals. Tolazoline increased cardiac output and decreased blood flow to the brain, kidney, carcass, and spleen. However, it is unlikely that these decreases in flow led to tissue hypoxemia because the animals were normoxemic and metabolic acidosis did not develop.

We did not include a group of animals to study the relationship between tolazoline and time because the smallest dose of drug was always given first.We expected, and found, that larger doses of drug would either not change or increase the effects seen with the smaller dose of drug. However, it would be useful to determine at a later date how long the effects of a dose of tolazoline last.

The third group was used to determine the effects of giving tolazoline to hypoxemic animals. This is the situation in which most infants are given tolazoline. The levels of cardiac output and myocardial blood flow present in hypoxemic animals given tolazoline were similar to those during hypoxemia alone (Group I). Instead of reducing cerebral and renal blood flow, as occurred when tolazoline was administered to normoxemic animals, tolazoline had no effect on flow to these organs when tolazoline was given to hypoxemic animals. Flow remained at levels present during hypoxemia alone. Thus, it appears that tolazoline does not interfere with the ability of these organs to regulate their blood flow. Organs such as the heart and brain meet their oxygen needs during hypoxemia primarily by increasing their blood flow and only minimally by increasing the extraction of oxygen from blood $(15,17,21)$. Hypoxemia usually increases the oxygen requirements of the heart (as indicated by an increase in the ratepressure product); (7) which increases the myocardial oxygen consumption $(9,17)$. We did not measure coronary sinus oxygen content in our studies and, therefore, cannot calculate myocardial oxygen consumption. However, the fact that the rate-pressure product was unaffected by hypoxemia and tolazoline suggests that the oxygen demands of the heart were being met.

In contrast to the heart and brain, organs such as the gut meet their oxygen requirements during hypoxemia by increasing the amount of oxygen extracted from the blood; blood flow remains constant or even declines (2). At some level of hypoxemia, the organ is unable to meet its oxygen requirements and its metabolic rate falls below the normoxemic value $(7,18)$. If tolazoline should alter the blood flow further or impair extraction of oxygen, then organ metabolism would be disrupted. We found no consistent change in blood flow to these organs when tolazoline was administered to hypoxemic lambs. Flows were similar to those present during hypoxemia alone. From our data, we cannot determine whether tolazoline interferes with oxygen extraction or oxygen uptake. However, it probably did not because metabolic acidosis did not occur. The rate-pressure product did not change when tolazoline was administered because decreases in blood pressure were offset by increases in heart rate. This suggests that myocardial oxygen consumption remained constant. Therefore, the increase in myocardial blood flow occurred in order to meet the increased volume of blood needed to provide normal oxygen delivery.

Tolazoline administration has been reported to have adverse effects on the gastrointestinal system of humans. Silverman et 
al. (26) and Goetzman et al. (11) described gastrointestinal bleeding in patients who were treated with tolazoline for as little as 2 days. One per cent of children developed gastric ulcers and $79 \%$ gastrointestinal complaints when tolazoline was used in 663 patients to treat polio (26). These effects were dose related. Ahlquist et al. (1) reported increased gastric acid stimulation and augmented histamine contractions of the gut with tolazoline, effects which could be blocked by atropine. Our data show no reduction in gut blood flow (including stomach blood flow) when tolazoline was infused. If similar effects occur in humans, it is unlikely that the gastrointestinal complaints reported are due to reduced blood flow.

Tolazoline has also been reported to have effects on the renal system of infants. Oliguria and/or hematuria occurred in 7 of 46 and renal failure in 2 of 46 infants treated with this drug (11). In another study, renal failure and death occurred in 1 of 20 infants receiving tolazoline (22). The difficulty with studies of this kind is that the patients have been hypoxemic and often hypotensive for a period of time during the course of their illness. As a result, renal failure may be due to these causes and not tolazoline administration. Our animals showed a small but significant reduction in renal blood flow with the onset of hypoxemia but no further reduction in renal blood flow occurred until we gave $10 \mathrm{mg} / \mathrm{kg} / \mathrm{h}$ of tolazoline. Therefore, it is difficult to account for the oliguria and/or renal failure reported in human infants on the basis of reduced renal blood flow, if infants and lambs respond to tolazoline similarly.

In summary, hypoxemia increases cardiac output and the blood flow to the heart and brain; it also decreases blood flow to the kidneys. Oxygen delivery is reduced to organs other than heart and brain with hypoxemia. The data also indicate that administering tolazoline to hypoxemic animals does not affect the distribution of blood flow caused by hypoxemia. Neither does it reduce the pulmonary artery pressure or improve oxygenation.

\section{REFERENCES}

1. Ahlquist RP, Huggins RA, Woodbury RA 1947 The pharmacology of benzylimidozoline (Priscol). J Pharmacol Exp Ther 89:271

2. Alward CT, Hook JB, Helmrath TA, Mattson JC, Bailie MD 1978 Effects of asphyxia on cardiac output and organ blood flow in the newborn piglet. Pediatr Res 12:824

3. Bland RD, Hansen TN, Haberkern CM, Bressack MA, Hafinski TA, Raj JU, Goldberg RB 1982 Lung fluid balance in lambs before and after birth. J Appl Physiol Respir Environ Exercise Physiol 53:992

4. Cassin S, Dawes GS, Mott JC, Ross BB, Strang LB 1964 The vascular resistance of the foetal and newly ventilated lung of the lamb. J Physiol (Lond) 171:61

5. Cotton EK 1965 The use of priscoline in the treatment of the hypoperfusion syndrome. Pediatrics $36: 149$

6. Drummond WH, Gregory GA, Heymann MA, Phibbs RH 1981 The inde- pendent effects of hyperventilation, tolazoline and dopamine on infants with persistent pulmonary hypertension. J Pediatr 98:603

7. Edelstone DI, Holzman IR 1982 Fetal intestinal oxygen consumption at various levels of oxygenation. Am J Physiol 242:H50

8. Edelstone DI 1984 Neonatal intestinal oxygen consumption during arterial hypoxemia. Am J Physiol, in press

9. Fisher DJ 1983 Left ventricular oxygen consumption and function in hypoxemia in conscious lambs. Am J Physiol 244:H664

10. Glantz SA 1981 A Primer of Biostatistics. McGraw-Hill Book Co, New York

11. Goetzman BW, Sunshine P, Johnson JD, Wennberg RP, Hackel A, Merten DF, Bartoletti AL, Silverman NH Neonatal hypoxemia and pulmonary vasospasm: response to tolazoline. J Pediatr 89:617

12. Goodman LS, Gilman A 1975 The Pharmacologic Basis of Therapeutics. MacMillan. New York

13. Hughes MJ, O'Brien LJ 1977 Liberation of endogenous compounds by tolazoline. Action Agents 7:225

14. lizuka H, Adach K. Halprin KM, Levine V 1977 Stimulation of the histamine (H2) receptor by tolazoline. J Invest Dermatol 69:442

15. Jones MD, Fraystman RJ, Simmon MR, Morteni RA 1981 Effects of changes in arterial $\mathrm{O}_{2}$ content on cerebral blood flow in the lamb. Am J Physiol 240:H209

16. Krones SN, Fabien G 1975 Successful treatment of "persistent fetal circulation" with tolazoline. Pediatr Res 9:367

17. Lee JC, Hallhorhan KH, Taylor JFN, Downing SE 1973 Coronary flow and myocardial metabolism in newborn lambs: effects of hypoxia and acidemia. Am J Physiol 224:1381

18. Lister G, Walter TKZ, Versmold HT, Heymann MA, Rudolph AM 1979 Oxygen delivery in lambs: cardiovascular and hematologic development. Am J Physiol 236: H668

19. McIntosh N, Waters RO 1979 Effects of tolazoline in severe hyaline membrane disease. Arch Dis Child 54:105

20. Pitt BR, Lister G 1984 Pulmonary metabolic function in the awake lamb: effect of development and hypoxia. J Appl Physiol, in press

21. Powers ER, Powell WJ 1973 Effect of arterial hypoxia on myocardial oxygen consumption. Circ Res 33:749

22. Purobit DM, Pai S, Levkoff AH 1978 Effects of tolazoline on persistent hypoxemia in neonatal respiratory distress. Crit Care Med 6:14

23. Rudolph A, Heymann M 1967 The circulation of the fetus in vitro. Methods for studying distribution of blood flow, cardiac ouput and organ blood flow. Circ Res 21:163

24. Rudolph AM, Paul H, Sommer LS, Paul MH, Nadas AS 1958 Effects of tolazoline hydrochloride (Priscoline) on circulatory dynamics of patients with pulmonary hypertension. Am Heart J 55:424

25. Rudolph AMR. Heymann MA 1970 Circulatory changes during growth in the fetal lamb. Circ Res 26:289

26. Silverman AG, Wilner HI, Okun R 1970 A case of gastrointestinal bleeding following the use of tolazoline. Toxicol Appl Pharmacol 16:318

27. Torrado A, Guignard JP, Prod'hom LH, Gautier E 1974 Hypoxia and renal function in newborns with respiratory distress syndrome (RDS). Helv Pediatr Acta 29:399

28. Tripp ME, Drummond WH, Heymann MA, Rudolph AM 1980 Hemodynamic effects of pulmonary arterial infusion of vasodilators in newborn lambs. Pediatr Res 14:1311

29. Verma SC, McNeill JH 1977 Investigations into the cardiac effects of tolazoline in guinea pig atria and ventricular strips. Agents Actions 7:191

30. Walker AM, Cannota JP, Dowling MH, Ritchie BC, Maloney JE 1979 Age dependent patterns of autonomic heart rate control during hypoxia in fetal and newborn lambs. Biol Neonate 35:198

31. Weinrab I, Michel IM 1975 Comparison of the effects of histamine and tolazoline on adenylate cyclase activity and guinea pig heart. J Med Chem $18: 23$ 